\title{
Vitamin D and immunomodulation in the skin: a useful affirmative nexus
}

Saptadip Samanta*(1)

Department of Physiology, Midnapore College, Midnapore, Paschim Medinipur, West Bengal 721101, India

*Correspondence: Saptadip Samanta, Department of Physiology, Midnapore College, Midnapore, Paschim Medinipur, West Bengal 721101, India. saptadip174@gmail.com

Academic Editor: Masutaka Furue, Kyushu University, Japan

Received: April 2, 2021 Accepted: June 2, 2021 Published: June 30, 2021

Cite this article: Samanta S. Vitamin D and immunomodulation in the skin: a useful affirmative nexus. Explor Immunol. 2021;1:90-111. https://doi.org/10.37349/ei.2021.00009

\begin{abstract}
Skin is the largest organ of the body having multifunctional activities. It has a dynamic cellular network with unique immunologic properties to maintain defensive actions, photoprotection, immune response, inflammation, tolerogenic capacity, wound healing, etc. The immune cells of the skin exhibit distinct properties. They can synthesize active vitamin $\mathrm{D}\left[1,24(\mathrm{OH})_{2} \mathrm{D}_{3}\right]$ and express vitamin $\mathrm{D}$ receptors. Any difficulties in the cutaneous immune system cause skin diseases (psoriasis, vitiligo, atopic dermatitis, skin carcinoma, and others). Vitamin D is an essential factor, exhibits immunomodulatory effects by regulating dendritic cells' maturation, lymphocytes' functions, and cytokine production. More specifically, vitamin D acts as an immune balancing agent, inhibits the exaggeration of immunostimulation. This vitamin suppresses T-helper 1 and T-helper 17 cell formation decreases inflammatory cytokines release and promotes the maturation of regulatory $\mathrm{T}$ cells and interleukin 10 secretion. The deficiency of this vitamin promotes the occurrence of immunoreactive disorders. Administration of vitamin D or its analogs is the therapeutic choice for the treatment of several skin diseases.
\end{abstract}

\section{Keywords}

Vitamin D, skin, immunomodulation, cytokines, anti-inflammatory effects, calcipotriol

\section{Introduction}

Vitamin D belongs to the fat-soluble group in the common classification of vitamins. A healthy diet meets the daily requirements of vitamins. They are essential for body growth, tissue repair, disease prevention, and immunomodulation [1,2]. Despite the diet, niacin and vitamin D are synthesized in the body. Amino acid tryptophan is the precursor for niacin synthesis. On the other hand, human skin can produce vitamin D. Normally, vitamin D increases intestinal calcium absorption, reduces urinary calcium loss resulting in the maintenance of calcium homeostasis in the body. Vitamin D regulates calcium metabolism in the bone as the vitamin D receptors (VDRs) are present in osteoblast cells. Calcitriol affects osteoblast proliferation, differentiation, and mineralization. Vitamin D stimulates the production of bone matrix proteins for

(C) The Author(s) 2021. This is an Open Access article licensed under a Creative Commons Attribution 4.0 International License (https://creativecommons.org/licenses/by/4.0/), which permits unrestricted use, sharing, adaptation, distribution and reproduction in any medium or format, for any purpose, even commercially, as long as you give appropriate credit to the original author(s) and the source, provide a link to the Creative Commons license, and indicate if changes were made. 
mineralization. Moreover, vitamin D regulates the expression of receptor activators of nuclear factor kappa $B$ (NF-кB; RANK) ligand (RANKL) and osteoprotegerin (OPG). RANKL binds with RANK and then advances the maturation and differentiation of osteoclast. Vitamin D tunes the osteoblastic and osteoclastic activity during bone remodeling. This traditional concept of vitamin D's functions has been expanded in more areas. Vitamin D has crucially involved in lymphocyte homing characteristics in the skin and gut, and immunomodulatory actions including regulation of inflammatory response. Vitamin D deficiency causes rickets, osteomalacia, and osteoporosis increases susceptibility to infection, and the risk of autoimmunity [3-5].

Skin is the largest organ of the body and performs various functions, including disease prevention, initiation of the immune response, tolerogenic activity, wound healing, and angiogenesis. Epidermis, dermis, and hypodermis are three distinct parts of the human skin. The epidermis has multiple (five) layers: stratum basale, stratum spinosum, stratum granulosum, stratum lucidum, stratum corneum (inner to outer direction). These layers have specific cellular characteristics and form the superficial covering of the body. The innermost part of the epidermis is abundantly richer with keratinocytes, melanocytes, and Langerhans cells (LCs) [6]. Keratinocytes are the major functional cell of the skin. Melanocytes synthesize melanin, which protects DNA from ultraviolet (UV) radiation [7]. LCs are the specific class of dendritic cells (DCs) that are associated with skin immunity. Moreover, Tlymphocytes, particularly CD8 ${ }^{+}$lymphocytes are also the common resident of the skin [6]. Skin-associated lymphoid tissue (SALT) is connected with immune defense. SALT provides local immune responses [8,9], protects the body from pathogenic invaders, and sometimes involves the pathophysiology of cutaneous diseases $[10,11]$.

Vitamin D is predominantly linked with skin immunity. Like other fat-soluble vitamins, the isoprene compound is the initial precursor of vitamin D (Figure 1). Biochemically vitamin D is a class of secosteroids. Plant steroid ergocalciferol is known as vitamin $D_{2}$, while cholecalciferol (vitamin $D_{3}$ ) is essentially present in the human. 7-dehydrocholesterol is converted to vitamin $\mathrm{D}_{3}$ in the epidermal layer of human skin after exposure to UVB radiation having a wavelength between $290 \mathrm{~nm}$ and $320 \mathrm{~nm}$ of sunlight [12] (Figure 1). The formation of $1,25(\mathrm{OH})_{2} \mathrm{D}_{3}$ makes the active form of vitamin $\mathrm{D}$, which binds with intracellular VDR for physiological action (Figure 1). Vitamin D maintains a balance between immunostimulatory and immunoregulatory actions. It promotes T-cell homing activity in the epidermis [13, 14]. The presence of VDR in the immune cells (macrophages, DCs, T- and B-cells) drives the immunomodulatory actions of vitamin D. It exerts anti-inflammatory effects, tolerogenic capacity, and prevents autoimmunity. The deficiency of vitamin D promotes autoimmune diseases, such as rheumatoid arthritis (RA), systemic lupus erythematosus (SLE), antiphospholipid syndrome (APS), hashimoto thyroiditis (HT), and multiple sclerosis (MS) [15, 16].

Skin is a very sensitive part of the body. It acts as an interface between the invaders and the protectors. Several pathogenic organisms, environmental toxicants, and others have given threatening from outside the skin. However, beneath the skin, a large number the immune-competent cells make a protective barrier. These cells can trigger innate response, adaptive immunity, as well as inflammatory response. Although, the inflammatory response is protective; it is the cause of several skin diseases [psoriasis, atopic dermatitis (AD), vitiligo, etc]. Vitamin D shows immunosuppressive action in skin inflammation, balances the cytokines levels, increases tolerogenic capacity, and anti-inflammatory cytokines. Inadequate vitamin D enhances the risk of skin diseases like psoriasis, ichthyosis, vitiligo, photoreactivity, AD, hair loss, and melanoma. The present review has focused on the immunomodulatory action of vitamin D with particular reference to cutaneous immunity and the impact of vitamin D on skin diseases.

\section{Sources, biochemical characteristics, and mode of action of vitamin D}

There are limited numbers of natural foods that contain a sufficient amount of vitamin D. Some animal products, such as fats, eggs, and milk supply vitamin D through diet. However, exposure to sunlight induces vitamin $\mathrm{D}$ synthesis in human skin from the precursor molecule 7-dehydrocholesterol (provitamin $\mathrm{D}_{3}$ ) to fulfill the daily requirements. 7-dehydrocholesterol is present in the cell membrane of epidermal basal and suprabasal keratinocytes, as well as dermal fibroblasts. The 7-dehydrocholesterol is converted to $\mathrm{D}_{3}$. After synthesis in the cutaneous surface, the plasma membrane releases vitamin $\mathrm{D}_{3}$ to the systemic circulation 
(Figure 1) where it binds with vitamin D-binding protein (DBP) for its circulation [17]. The cutaneous synthesis has been varied from individual to individual. The aged people have thinner skin that reduces the production of vitamin D [18, 19]. Ardawi et al. [20] reported that obesity decreased the vitamin D levels in the individual. Adipocytes can take up vitamin $\mathrm{D}_{3}$ due to its lipid solubility and subsequently be stored in subcutaneous or omental fat for further use [21]. Ergosterol from plants and fungi is used as the commercial source of this vitamin $[22,23]$. Commercial vitamin supplementation is sometimes mixed with vitamin $\mathrm{D}_{3}$ and vitamin $\mathrm{D}_{2}$. Biologically vitamin $\mathrm{D}_{2}$ has less affinity for the vitamin DBP in the plasma and shows a short half-life [24].

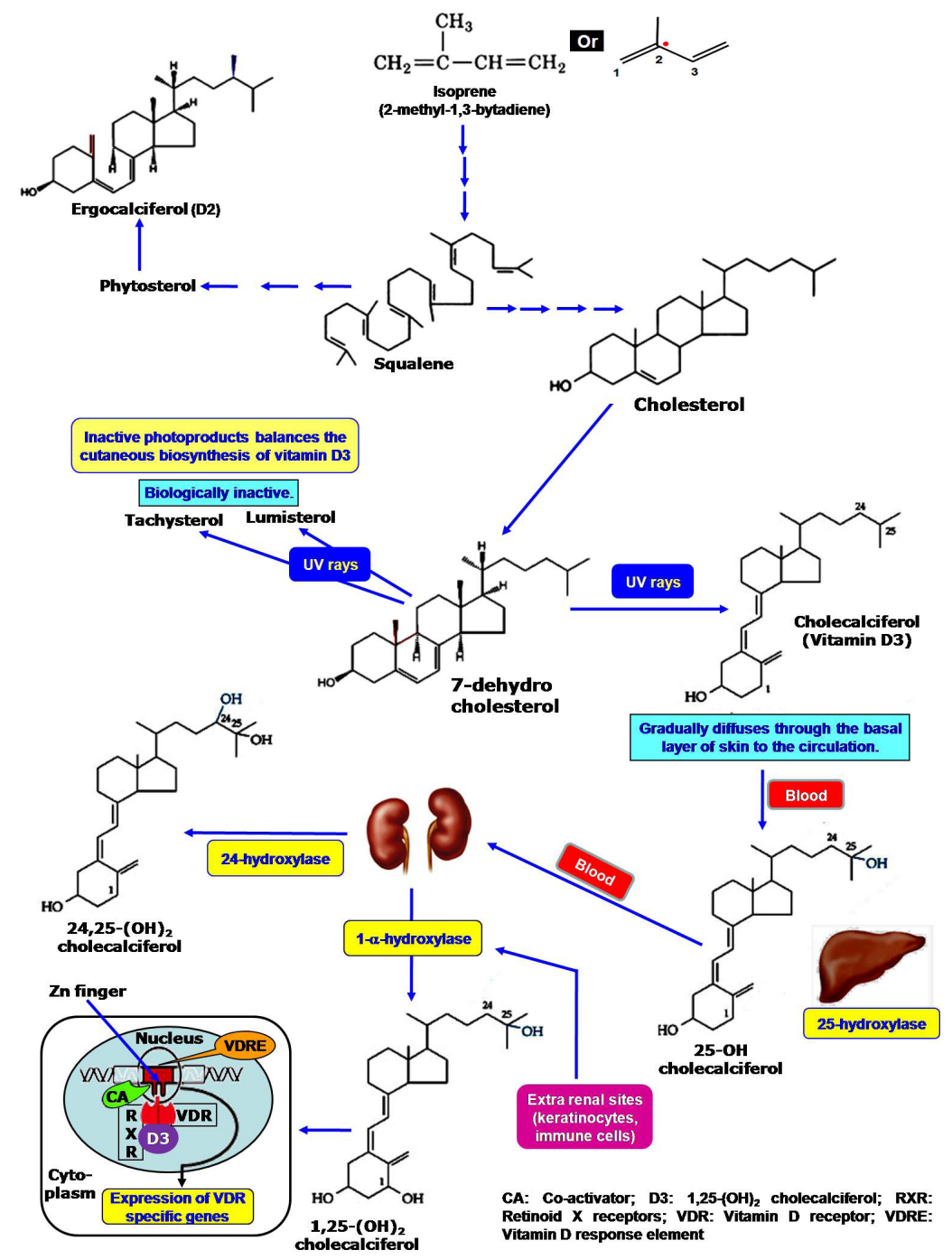

Figure 1. Cutaneous synthesis of Vitamin D, its activation and mode of action. Cholesterol is the primary precursor molecule of vitamin $\mathrm{D}$, which is synthesized from isoprene compound. In the epidermal cells of the skin, cholesterol is present as 7-dehydrocholesterol that is converted to vitamin D on exposure to UVB irradiation. At the subsequent activation stage, hepatic 25-hydroxylase converts the vitamin $\mathrm{D}$ to 25 -hydroxycholecalciferol. Another hydroxylation reaction produces 1,25-dihydroxycholecalciferol as an active component by the action of enzyme 1- $\alpha$ hydroxylase of renal cells. The formation of 24,25-dihydroxycholecalciferol lowers the active form of vitamin $D$. The cellular activity of vitamin $D$ is started by the interaction with the intracellular VDR. The vitamin $\mathrm{D}$-VDR complex binds to the VDRE of DNA by using the Zn-finger system in the presence of the co-activator. VDRE: vitamin D response element

The native form of vitamin D is not the active component. 25-hydroxylase [cytochrome P450 (CYP)27A1/ CYP2R1/CYP2D25] a class of CYP, catalyzes the hydroxylation reaction at the C-25 position of the vitamin D in theliver [25]. Another hydroxylation occurs in the kidney where 1- $\alpha$-hydroxylase incorporates a hydroxyl group to the 25-OH vitamin D (calcidiol) to form 1,25(OH), vitamin D (calcitriol or 1,25-dihydroxy cholecalciferol), which exerts all the biological activities of vitamin D. 1- $\alpha$-hydroxylase is a specific type of parathyroid hormone-dependent CYP monooxygenase 25-hydroxyvitamin $\mathrm{D}_{3} 1$ alpha-hydroxylase (CYP27B1) enzyme. However, 24-hydroxylase (CYP24) includes another hydroxyl group at the C-24 position of the active vitamin D to produce $24,25-\mathrm{OH}$ vitamin $\mathrm{D}$, which is functionally inactive. A regulatory feedback mechanism maintains 
the levels of active vitamin D. High levels of $1,25(\mathrm{OH})_{2}$ vitamin D repress the expression of 1- $\alpha$-hydroxylase in the kidney and alternatively, induce the expression of CYP24 for inactivation of vitamin D. Thus, circulating vitamin $\mathrm{D}$ is in a tight regulation system $[4,12,26]$. Besides the kidney, CYP27B1 is also expressed in the extra-renal tissues, including the brain, lungs, placenta, and macrophages. A separate regulatory mechanism maintains the activity of CYP27B1 in the extra-renal site. Cytokines like interferon (IFN)-gamma (IFN- $\gamma$ ), interleukin (IL)-1, or tumor necrosis factor-alpha (TNF- $\alpha$ ) regulate the expression of CYP27B1 in place of parathyroid hormone. Additionally, macrophages produce a variant form of inactive CYP24 that continues the prolonged activity of vitamin D in the immune compartment [27]. Shahriari et al. [28] reported that a reduced number of active nephrons and high levels of fibroblast growth factor (FGF)-23 affect the circulating calcitriol levels.

Vitamin D is one of the non-plant steroid-derived natural antioxidants that has been synthesized in the human cell. This endogenous cholesterol-derived component fights against the stress response to protect the cells $[29,30]$. This cholesterol-derived molecule shows functional characteristics similar to steroid hormone instead of fat-soluble vitamins. The action of vitamin D depends on the expression of VDR. Immune cells like macrophages, DCs, T-cells, and B-cells express VDR $[4,15]$. Vitamin DBP help to transport vitamin D through circulation. At the cellular level, vitamin D binds with VDR (a nuclear receptor superfamily member). The mechanism of action is similar to retinoic acid and thyroid hormone. 1,25 dihydroxy cholecalciferol migrates into the nuclei of the target cells and binds with high-affinity VDRs. After binding vitamin D with VDR, a conformational change occurs, allowing its dimerization with retinoid X receptor (RXR). 11-cis retinoic acid is the ligand of RXR. The heterodimer complex of VDR-RXR binds to vitamin D response element (VDRE) in association with co-activators. The interaction of VDR-RXR heterodimer with DNA is mediated through zinc finger (Zn-finger). Finally, vitamin D modulates the activity of the promoter regions of vitamin D-targeted genes for their expression [31,32].

\section{The basic architecture of the skin and effects of vitamin D}

\section{The fundamental structure of the skin}

The skin forms the superficial covering of the entire body, comprise the epidermis and the dermis. Beneath the dermis, the layer is called the hypodermis. The epidermis is the outmost region. It is a thin layer, composed of stratified squamous epithelium that is divided into several layers. The deepest layer is called the stratum basale, which acts as the germinal center. The stratum basale consists of a single layer of undifferentiated cells with constant mitotic activity [33]. The cells are in contact with the dermis. Four types of cells comprise the stratum basale: keratinocytes (columnar type), melanocytes, tactile cells (Merkel cells), and nonpigmented granular dendrocytes (LCs). The keratinocytes of the stratum basale constantly divide and produce new cells that are pushed towards the surface of the epidermis. These cells produce a specific type of protein called keratins ( $\mathrm{K} 5$ and K14), making the skin waterproof. When the keratinocytes are pushed away from the vascular bed of the dermis, the cells suffer from deprivation of nutrient and oxygen supply. This condition starts the keratinization process where the cells are filled with keratin along with the nuclear-disintegrated state. Finally, keratinocytes reach the outer surface of the skin. They appear as dead scales at the superficial layer containing full of keratin enclosed by a loose cell membrane.

Melanocytes are specialized epithelial cells responsible for the synthesis of melanin pigment. Tactile cells act as a sensory receptor for tactile perception. LCs are associated with immune defense. Above the stratum basale, the other layers are stratum spinosum, stratum granulosum, stratum lucidum, stratum corneum. The stratum spinosum contains several layers of cells. These cells arise from the keratinocytes of the basal stratum after differentiation. They exhibit a spiny appearance on their surfaces due to the spine-like extensions. The stratum granulosum has three or four layers of flattened type granular cells (keratinocytes) that contain fibers of keratin (keratohyalin) and blackened granules in their cytoplasm. Stratum lucidum is a thin, clear layer, exists only in the lips and in the thickened skin of the soles and palms. The stratum corneum is the uppermost layer of the skin. It is composed of 25 to 30 layers of keratinized flattened, scale-like dead cells. Several appendages like hair follicles, eccrine sweat glands, sebaceous glands, and apocrine glands are 
associated with the skin. These structures are involved in various physiological functions like regulation of body temperature, prevention of infection, maintenance of moisture, and smoothness of the skin.

\section{Role of vitamin D on the functions of keratinocytes}

Keratinocytes are actively participating in vitamin D metabolism. They synthesize vitamin D from 7-dehydrocholesterol and express CYP27A1 and CYP27B1 for activation of vitamin D to produce 1,25(OH) cholecalciferol. These cells express VDR that ensures the action of vitamin D through an autocrine/paracrine manner [34]. Vitamin D differentially regulates the proliferation and differentiation of keratinocytes. VDR in association with co-activators like VDR-interacting protein (DRIP) and steroid receptor co-activator (SRC) promotes the differentiation process of keratinocytes [35]. Gniadecki [36] observed the stimulatory and inhibitory effects of $1,25(\mathrm{OH})_{2} \mathrm{D}_{3}$ on keratinocyte proliferation in a cell culture study. He reported that a low concentration of $1,25(\mathrm{OH})_{2} \mathrm{D}_{3}\left(10^{-11} \mathrm{~mol} / \mathrm{L}\right.$ or less $)$ in association with calcium $(0.15 \mathrm{mmol} / \mathrm{L})$ restricts the cell cycle in the late G1 phase, resulting in inhibition of keratinocyte proliferation. Reduction in the expression of c-Myc, cyclin D, and elevated levels of cell cycle inhibitors p21cip, and p27kip inhibit the cell cycle [37]. High concentrations of calcium $\left(1.8 \mathrm{mmol} / \mathrm{L}\right.$ ) and $1,25(\mathrm{OH})_{2} \mathrm{D}_{3}$ (greater than $10^{-11}$ $\mathrm{mol} / \mathrm{L}$ ) stimulates cell growth by pushing the cell in the $\mathrm{S}$ phase of the cell cycle [36]. Moreover, elevated levels of calcium and activation of phospholipase C- $\gamma 1$ are essential for the differentiation of keratinocytes. Calcitriol induces the synthesis of involucrin, transglutaminase, loricrin, and filaggrin in keratinocytes during differentiation [34, 38]. Xie et al. [39] had indicated the occurrence of impaired epidermal differentiation and the appearance of inappropriate levels of involucrin, profilaggrin, and loricrin in VDR knockout mice. Vitamin D acts as an anti-apoptotic agent at physiological concentrations. This vitamin rescues the keratinocytes from the adverse effects of pro-apoptotic stimuli like ceramide, UV radiation, and TNF- $\alpha$ [34]. VDR-dependent synthesis of glucosylceramide (GlcCer) critically maintains the permeability barrier of the epidermis. VDR SRC2, or SRC3 is essential for GlcCer production. Silencing either VDR, SRC2 or SRC3 reduces GlcCer synthesis by altering the expression of fatty acid elongase and ceramide glucosyltransferase. This silencing adversely affects the formation of epidermal GlcCer species, lamellar body, and the expression of the lipid transporter ATP-binding cassette transporter protein 12, resulting in an abnormal permeability barrier. VDR null mice also exhibit defective barrier function [35]. Thus, VDR and its co-activator are indispensable for the epidermis-specific sphingolipid synthesis and maintenance of barrier.

\section{Different types of immune cells in the compartment of the skin}

Epidermis, dermis, cutaneous appendages, and subcutaneous tissue are the structural part of the skin [40]. The skin has a complex immune system. DCs, LCs, mast cells, B- and T-lymphocytes, and keratinocytes comprise the immune compartment of the skin $[10,41]$. LCs are the specialized subset of DCs that are abundantly present in the epidermal region of the skin. The surface marker of LCs of mice and humans is langerin [42]. The cutaneous immune system provides body defense against pathogens (bacteria, virus, protozoa, and others) and antigens (protein, polysaccharides, glycoprotein, and others). Varieties of immune cells [T-cells, B-cells, antigen-presenting cells (APCs)] and different biomolecules (cytokines, chemokines) have been associated with the immune network. Impaired immune reactions dampen the self tissue. Any mistake in the regulatory process exaggerates inflammatory response and promotes the consequence of many diseases.

\section{Role of keratinocytes and melanocytes}

Keratinocytes play an important role in the immune response of the skin. They can potentially recognize pathogenic organisms through pathogen-associated molecular patterns (PAMPs) or damage-associated molecular patterns (DAMPs) [10]. Microbial lipopolysaccharides (LPS), flagellins, unmethylated cytosine-phosphate-guanine (CpG) DNA sequences, teichoic acids, mannose-rich oligosaccharides act as PAMPs $[43,44]$. The keratinocytes express cell surface and cytoplasmic receptors for the detection of microbial products. These molecules are termed pattern recognition receptors (PRRs). These are cell surface Toll-like receptors (TLRs), intracellular nucleotide-binding oligomerization domain (NOD)- 
like receptors (NLRs). The epidermal keratinocytes express TLR1, TLR2, TLR4, TLR5, and TLR6, along with endosomal (TLR3 and TLR9) [43]. The activation of TLRs induces innate and adaptive immunity. The TLRs of keratinocytes trigger the dermal immune response as the compartment of the dermis has associated with the immune network containing varieties of immune cells like CD4+ ${ }^{+}$-lymphocytes, $\gamma \delta$ T-lymphocytes, APCs, natural killer (NK) cells, and mast cells [9]. Activation of T-helper (Th)1 cells promotes the release of IFN-alpha (IFN- $\alpha$ ) and IFN-beta (IFN- $\beta$ ) [44]. NLRs are essential for the recognition of irritants and toxins. Activation of NLRs stimulates pro-inflammatory signaling through inflammasomes that finally activate a specific protein apoptosis-associated speck-like protein containing a caspase recruitment domain (CARD; ASC), and pro-caspase-1 followed by induction of immune response $[45,46]$. Moreover, keratinocytes synthesize cytokines, including IL-1, IL-6, IL-10, IL17, IL-18, IL-22, and TNF- $\alpha$ (Figure 2) [6]. To increase the communication and co-operation with other cells, keratinocytes express chemokines, such as C-X-C motif ligand (CXCL)1 and CXCL8, CXCL9, CXCL10, CXCL11, and CC chemokine ligand (CCL) 20 (Figure 2). They attract immune cells like LCs. CXCL1 and CXCL8 increase neutrophil infiltration in the epidermis [47]. Keratinocytes can increase the $\mathrm{CD}^{+}{ }^{+}$and $\mathrm{CD} 8^{+} \mathrm{T}$-cells responses by modulating the expression of Th1 (IL-1, IFN- $\gamma$, TNF- $\alpha$ ) or Th2 (IL-4, IL-5, IL-6) cytokines [48]. Melanin synthesizing melanocytes can induce local immune responses, trigger phagocytosis, and produces IL-1 $\beta$, IL-6, TNF- $\alpha$, IL-8, IFN- $\gamma$. These cells exhibit variety of TLRs like TLR1, - 2, -3, -4, -6, -7, and -9, expresses leukocyte recruiting chemokines (CCL2, CCL3, and CCL5) [49]. TLR signaling in association with adaptor proteins myeloid differentiation factor 88 (MyD88), toll/ IL-1 receptor domain-containing adaptor protein (TIRAP)/MyD88 adapter-like (Mal), TIR-domain-containing adapter-inducing interferon-beta (TRIF), and transverse rectus abdominis (TRAM) activates NF- $\mathrm{KB}$ and mitogen-activated protein kinase (MAPK) pathways. The induction of the NF- $\kappa B$ pathway promotes the expression of antimicrobial peptides (AMPs), IL-6, TNF- $\alpha$, IL-8, and IL-12, resulting in stimulation of inflammatory response, recruitment of phagocytic cells [50].

\section{Functions of immune-competent cells}

Macrophages, monocytes, DCs, LCs are the APCs of the skin. In humans, there are four subtypes of DCs: LCs, dermal dendrocytes (DDs), plasmacytoid DCs (pDCs), and inflammatory DCs (iDCs). LCs and DDs express CD13 and CD33, can activate CD4 ${ }^{+}$and CD8 ${ }^{+}$T-cells, secrets IL-12. However, Shklovskaya et al. [51] reported that despite the inflammatory activity LCs induce tolerogenic responses. This effect is mediated by tolerizing $\mathrm{CD}^{+} \mathrm{T}$-cells and the formation of Treg cells for the production of IL-10 [52, 53]. pDCs release IFN- $\alpha$, IL-12 and also activate CD4 ${ }^{+}$and $\mathrm{CD}^{+}{ }^{+} \mathrm{T}$-cells (Figure 2). iDCs express CD206 and immunoglobulin (Ig) fragment crystallizable (Fc)-like receptors for IgE, promote allergic response $[6,10,54]$. The main functions of DCs are capturing the antigens and represent the T-cells with major histocompatibility complex (MHC) class II after processing. Thus, DCs are involved in $\mathrm{T} \mathrm{CD} 4^{+}$and Treg activation, and secretion of different cytokines.

The skin has a much greater population of T lymphocytes than that of blood. Clark et al. [55] reported that approximately 20 billion T-cells reside in the skin. This number is approximately double in comparison to the T-cell population of the blood. The epidermal T-cells are located in the suprabasal and stratum basale, nearer to the LCs. Equal numbers of $\mathrm{CD} 4^{+}$and $\mathrm{CD} 8^{+}$lymphocytes are distributed within the skin, particularly to the capillaries and the epidermal-dermal junction [56, 57]. They are mostly memory T-cells [58. 59], express cutaneous lymphocyte-associated antigen and make the first-line defense against pathogenic invaders [60].

Cutaneous T-cells are a heterogeneous population, comprise Th1, Th2, Th3, Th17, and Treg cells [10]. Moreover, other subpopulations of T-cells like Th9, Th22, Th25 are also found in the skin during infection. T-cells secrete different types of cytokines for the activation of B-cells, antibody production, induction of inflammatory response, and regulation of immune response. The cytokine profile of T-cells are: i) Th1: IFN- $\gamma$, TNF- $\alpha$ IL-2; ii) Th2: IL-4, IL-5, IL-6, IL-13; iii) Th3: transforming growth factor- $\beta$ (TGF- $\beta$ ), IL-4, IL-10; iv) Th17: IL-17, IL-22; v) Th22: IL-22, TGF- $\beta$, IL-13, TNF- $\alpha$; vi) Th25: IL-25, IL-4, IL-13; vii) Th9: IL-9, IL-10, IL-22, IL-4, TGF- $\beta$; viii) Treg: IL-10, TGF- $\beta[6,61]$. Good numbers of mast cells are present in the skin. They express complement factor C5a (CD88) and IgE receptors [62], involve in the release of vasoactive and proinflammatory agents. NK cells give IL-12, IFN- $\gamma$, produce granzyme, perforin, and granulysin that can directly 
destroy the microorganisms. NKT cells release IFN- $\gamma$, IL-22, IL-17 and induce the production of AMPs [63]. Very few B-lymphocytes are present in normal skin but antigenic challenges increase their migration [6]. B-lymphocytes move toward the site of the antigenic microenvironment, where APCs start the activation of naive lymphocytes [64]. B-cells are involved in both immunostimulatory and immunosuppressive actions. B lymphocytes play an important role during Staphylococcus aureus skin infections. They produce specific antibodies, induce opsonization and phagocytosis by macrophages and neutrophils [65]. Infiltration of B lymphocytes causes skin lesions AD [64]. Another subpopulation is regulatory B (Breg) lymphocytes. They are capable to release IL-10 as an anti-inflammatory agent [66].

\section{Immunomodulatory effects of vitamin D}

Skin exerts first-line defense against infections. APCs, T-cells, B-cells, NK cells, and others are the resident immune cells in the skin [10,34]. These cells bear VDRs having a high affinity for effective binding with vitamin D [67]. AMPs are the most important factors in the skin that exert challenges to microbial invaders. Different cells like keratinocytes, sebocytes, eccrine gland cells, mast cells, neutrophils, and NK cells are the contributor of AMPs. They can synthesize more than 20 types of antimicrobial proteins; among these, $\beta$-defensin and cathelicidins are most effective $[68,69]$. Humans bear a single copy of the cathelicidin gene that produces peptide human cationic antimicrobial protein (hCAP18). Cathelicidin LL-37 appears as the final product from peptide hCAP18 through cleavage [34]. During infection, keratinocytes secret IL-17 and IL-22 that induce the production of AMPs [70].

\section{Dynamic actions of vitamin D}

Several studies have established the role of vitamin D on immunity. The immune cells can synthesize active vitamin $\mathrm{D}$ but the process is differentially regulated. The expression of 1- $\alpha$-hydroxylase is not parathyroid hormone-dependent. 25-OH vitamin D, IFN- $\gamma$, IL-1, TNF- $\alpha$ induce the expression of 1- $\alpha$-hydroxylase in the immune cells. At the immunologic microenvironment, vitamin D acts through the autocrine/paracrine fashion $[15,71,72]$. Vitamin $D$ has an impact on both innate and adaptive immunity. Several in vitro experiments had established the immunomodulatory role of $1,25(\mathrm{OH})_{2}$ vitamin $\mathrm{D}$ on innate and adaptive immunity. Vitamin D modulates the maturation of macrophages, LCs, B-cells, and T-cells (particularly Th2 cells) (Figure 2) [72]. It advances the development of Treg cells but diminishes differentiation of Th1 and Th17 cells; that favor anti-inflammatory effects (Figure 2) [73]. PAMPs or DAMPs activate immune cells through TLR response. An in vitro study had revealed that vitamin D modulates TLR-induced DC maturation, promotes IL-8, IL-6, and IL-10 production, and inhibits LPS-dependent IL-12 secretion [74]. The VDR polymorphisms delink the vitamin D-mediated immunomodulatory effects [75-77]. Mutant VDR cannot regulate Th1 response and IFN- $\gamma$, IL-17A, and IL-22 secretion in the presence of vitamin D [78]. Thus, defective VDR overrides the immunomodulatory effects of calcitriol.

\section{Effects on AMPs synthesis}

Vitamin D has an effect on hCAP18/LL-37 and $\beta$-defensin synthesis [34, 79]. Disruption of cutaneous barrier and skin infection increases the expression of AMPs. Infectious challenges enhance the expression of CYP27B1 in the microenvironment of the cutaneous compartment, which uplifts the local synthesis of active vitamin D. Skin injury increases TLR-2 response that elevates the vitamin D-induced expression of AMPs [80, 81]. Several studies have shown the role of vitamin D on the expression of hCAP18/LL37 and defensins after supplementation of $1,25(\mathrm{OH})_{2} \mathrm{D}_{3}$. Lee et al. [82] reported that the application of vitamin D in cultured sebocytes promotes the expression of cathelicidin. An in vivo experiment on human skin had established the inductive effects of vitamin D during wounding. Topical application of vitamin $\mathrm{D}$ analog calcipotriol increases the expression of hCAP18/LL-37 to prevent infection. $1,25(\mathrm{OH})_{2} \mathrm{D}_{3}$ acts through activating protein-1 (AP-1) and p38-induced peroxisome proliferator-activated receptor- $\gamma$ (PPAR- $\gamma$ ) mediated signaling for the expression of human beta-defensin 3 (HBD-3) and cathelicidin (hCAP18) in human keratinocytes (Figure 2) [83]. At the molecular level, the mechanism of induction of cathelicidin and $\beta$-defensin is slightly different. $1,25(\mathrm{OH})_{2} \mathrm{D}$-VDR complex binds with VDRE at the 
promoter region of the cathelicidin gene. Alternatively, expression of the $\beta$-defensin is mediated by NF$\kappa \mathrm{B}$ and 1,25(OH) $)_{2} \mathrm{D}-\mathrm{VDR}$ complex [81]. Moreover, $1,25(\mathrm{OH})_{2} \mathrm{D}_{3}$ induces the expression of specific serine proteases kallikrein-related peptidase (KLK) 5 and KLK7. KLK5 is the tryptic type enzyme, while KLK7 belongs to chymotryptic type protease. These serine proteases are responsible for the processing of proform cathelicidin, an active form of cathelicidin. Vitamin D-dependent increased KLK expression differentially regulates the processing of cathelicidin precursor protein hCAP18 [84, 85]. Thus, vitamin D influences the expression and antimicrobial activity of cathelicidin and other AMPs [86]. Mice deficient with the serine protease inhibitor lympho-epithelial Kazal-type-related inhibitor (LEKTI) showed significant improvement in antimicrobial activity [84].

\section{Effects on innate immunity}

The cells of the innate immunity express VDR. $1,25(\mathrm{OH})_{2} \mathrm{D}_{3}$-VDR-complex modulates innate immunity by controlling the maturation and activation of NKT cells and NK cells, as well as the production of IL-4 and IFN- $\gamma$. Vitamin D also elevates IL-1 $\beta$ and IL-8 levels, while restricts the phagocytic activity of neutrophils and macrophages [87]. Vitamin D acts as an anti-inflammatory agent. It favors the polarization of M2 macrophages that potentially enable to producce of anti-inflammatory cytokines IL-10, TGF- $\beta$ (Figure 2) [88]. M2 macrophages induce collagen synthesis, extracellular matrix formation during tissue repair and healing. Almerighi et al. [89] reported that $1,25(\mathrm{OH})_{2}$ vitamin D inhibits the expression of inflammatory cytokines like IL-1, IL-6, IL-8, IL-12, and TNF- $\alpha$. To potentiate the effectiveness of innate immunity, active vitamin D increases the synthesis of AMPs (cathelicidin and $\beta$-defensin) because microbial infection induces CD40 ligand and IFN- $\gamma$ release to enhance the VDR and CYP27B1-hydroxylase expression [90].

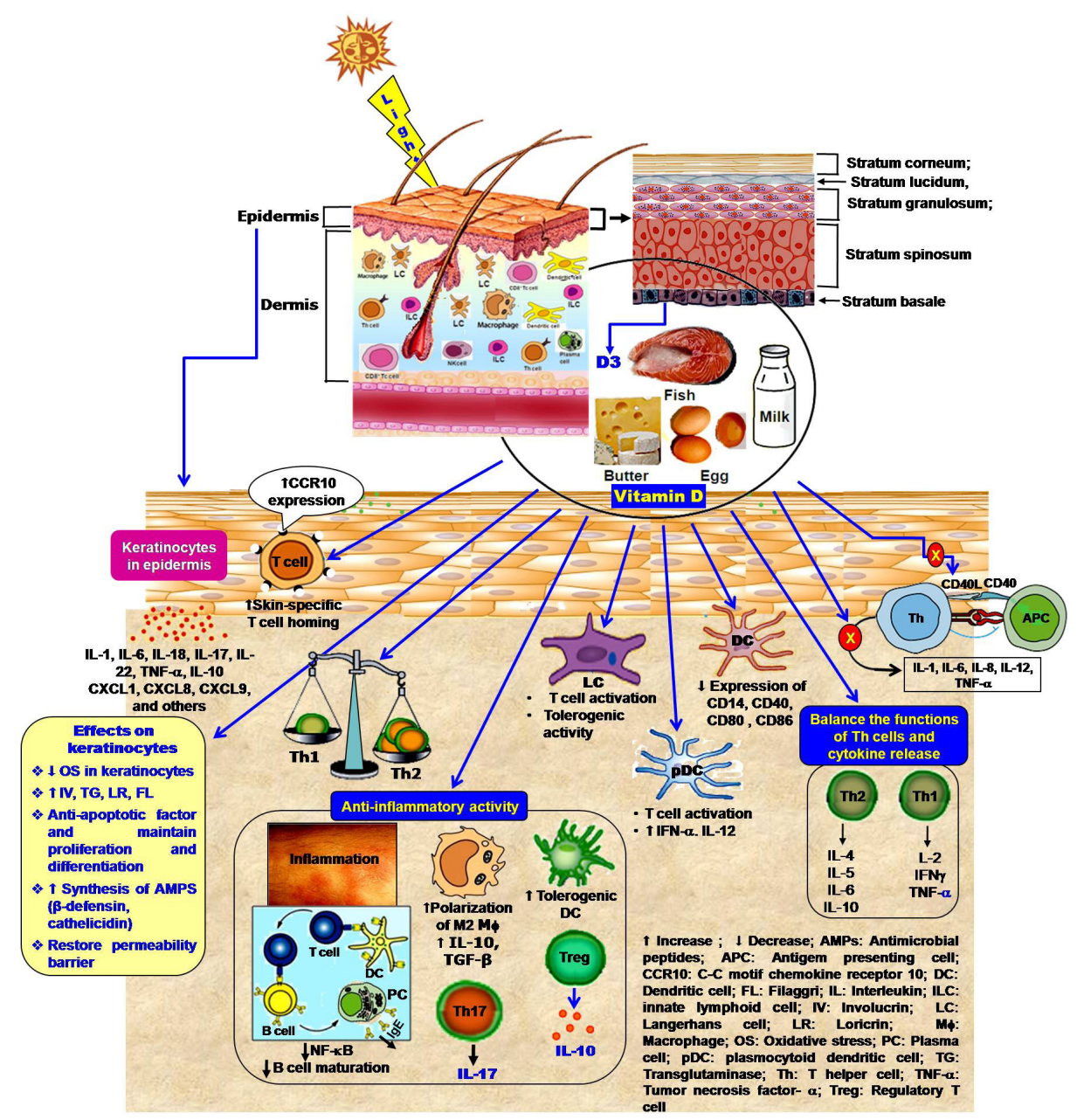

Figure 2. Immunomodulatory effects of vitamin in the cutaneous immune compartment. 1,25(OH)2 vitamin D polarizes the Th2 development and maintains a balance in cytokine secretion. Active vitamin $D$ regulates the inflammatory response by inhibition of Th17 cell development and facilitation of Treg cell generation, formation of tolerogenic DC, the release of IL-10, and suppression of IgE synthesis. Vitamin D also inhibits the expression of the co-stimulatory molecule on DCs and blocks the activation of Th cells, as well as cytokine production. Moreover, vitamin D facilitates the skin-homing capacity of T-cell 


\section{Effects on lymphocyte-homing}

$1,25(\mathrm{OH})_{2}$ vitamin D increases lymphocyte-homing capacity in the skin. It influences the T-cell migration and their homing beneath the skin surface. The subset of cutaneous memory T-cells having lymphocyteassociated antigen (CLA $)$ expresses vitamin D-induced CC-chemokine receptor (CCR)10, which binds with the skin-specific chemokine CCL27. By increasing the expression of CCR10, $1,25(\mathrm{OH})_{2} \mathrm{D}_{3}$ promotes the T-cell-homing in the skin (Figure 2) $[13,91]$. Epidermal keratinocytes exclusively synthesize chemokine CCL27 [13]. However, $1,25(\mathrm{OH})_{2} \mathrm{D}_{3}$ reduces the gut-homing capacity of the T-cells. It inhibits the expression of $\alpha_{4} \beta_{7}$ integrins and CCR9 on T-cells this process is upregulated by vitamin A [14].

\section{Effects on adaptive immunity}

T-cells B-cells and APCs express VDR. 1,25(OH) ${ }_{2} \mathrm{D}_{3}$-VDR complex modulates IL-2 levels and regulates the maturation of $\mathrm{CD}^{+}$lymphocytes. Alternatively, vitamin D influences Foxp3 ${ }^{+}$Treg cell differentiation [92]. Chirumbolo et al. [30] reported that vitamin D upregulates the expression of TLR2, NOD2, and IL-1 $\beta$ in the steps of DC-mediated Th maturation towards Treg cells. Moreover, vitamin D enhances the number of memory T-cells [93]. The extensive study by Dam et al. [94] on DCs and LCs had revealed that vitamin D regulates the maturation of APCs and antigen presentation to the T-cells. They used 1,25(OH) $)_{2} \mathrm{D}_{3}$ and the vitamin $\mathrm{D}_{3}$ analog calcipotriol for this purpose. Topical application of calcipotriol on normal human skin decreases the number of CD1 $\mathrm{a}^{+}$DCs and fewer dendrites per cell with altered dendritic morphology. Administration of both $1,25(\mathrm{OH})_{2} \mathrm{D}_{3}$ and calcipotriol in LC (isolated from human skin) enriched cell suspensions inhibit the LCsinduced antigen-dependent T-cell proliferation. This study strongly supports the immunosuppressive effects of vitamin D on the skin (Figure 2). Naïve B-cells lower the expression of VDR as vitamin D inhibits B-cell proliferation and maturation. Additionally, vitamin D decreases IgG and IgM by inhibiting the differentiation of plasma cells [95].

\section{Anti-inflammatory effects of vitamin D}

Vitamin D maintains the balance in the skin immune response (Figure 2). It acts as an immunosuppressive agent, affects antigen presentation by preventing the functions of LCs and other APCs [94, 96]. Active vitamin D restricts the maturation of APCs [24]. Previously, Penna and Adorini [96] reported that 1,25(OH) vitamin D inhibits differentiation, maturation, activation, and survival of DCs. These cells are the major APC, are mostly present in the epidermal and dermal region. The maturation of DCs is crucially important as they represent the antigen to the Th cells (primarily the Th1 subset). Immature DCs can not activate T-cells due to inappropriate surface markers. Vitamin D inhibits the expression of human leukocyte antigen (HLA)-DR (HLA-DR), CD14, CD40, CD80, CD83, and CD86 (Figure 2) as co-stimulatory molecules and MHC II on the surface of DCs at the developmental stage [30,96]. This effect modulates the activation of T-cells and the secretion of cytokines. Vitamin D induces the maturation of CD $4^{+} \mathrm{CD} 25^{+}$Treg cells (Figure 2). To control the inflammation, vitamin D suppresses the activity of the effector T-cell, promotes the trafficking of Treg cells at the inflammatory site [97]. Topical application of vitamin D analog calcipotriol promotes the development of Treg cells in the skin [98]. Vitamin D favors the development of tolerogenic DCs as an upliftment factor of anti-inflammatory effects [99]. VDR-induced activation of tolerogenic DCs increases the number of Treg cells and prevents allograft rejection and autoimmune diseases [100]. Gorman et al. [101] reported that dietary vitamin $\mathrm{D}$ increases the Treg cell $\left(\mathrm{CD}^{+} \mathrm{CD}^{+} \mathrm{CD}^{2} 5^{+} \mathrm{Foxp}^{+}\right)$population and their migration to the skin-associated lymph nodes. Vitamin D-mediated Treg cell maturation and the suppressive activity of Treg cells in the skin-draining lymph nodes inhibit cutaneous inflammation. Vitamin $\mathrm{D}$ analog calcipotriol shows immunosuppressive effects by inhibiting $\mathrm{CD}^{+} \mathrm{T}$ priming and lowering the numbers of LCs in the experimental model of transcutaneous immunization technique. Calcipotriol promotes the Treg cell activity that subsequently inhibits the activity of CD8 ${ }^{+}$T-cells and release of IFN- $\gamma$. These events indicate the anti-inflammatory properties of vitamin D or its analog [98]. 


\section{Skin diseases and impact of vitamin D}

Normally, the immune system exerts defensive action against invading pathogens in a precise manner. An inflammatory response is a coordinative action of immune cells, cytokines, and other signaling molecules to exercise the effects. Any dysfunction of the immune system causes fatal diseases. The most common symptoms are allergic response, inflammatory diseases, and autoimmunity. An intricate relationship exists between vitamin D and skin functions. Deficiency of vitamin D increases the susceptibility of different skin diseases, including skin cancer, psoriasis, ichthyosis, autoimmune skin disorders (vitiligo, blistering disorders, scleroderma, and SLE), AD, acne, hair loss, infections, and photodermatosis [24, 102].

\section{Psoriasis}

Psoriasis is a chronic inflammatory disease of the skin. Dysregulation of the immune cell activity is the vital cause of psoriasis. Different cells and agents like T-cells, pDCs, myeloid DCs (CD11 $\mathrm{c}^{+} \mathrm{mDCs}$ ), neutrophils and NK cells, and high levels of AMPs (like $\beta$-defensins, S100 proteins, or LL-37) start the psoriatic lesions $[34,103]$. Lande et al. [104] reported that IFN- $\alpha$ from pDCs and host DNA along with AMPs trigger the inflammatory cascade in psoriasis. IFN- $\alpha$-mediated activation of effector T-cell can advance this autoimmune pathogenic lesion. myeloid DC (mDC) synthesizes IL-20, IL-12, IL-23, and recombinant TNF- $\alpha$ (rTNF- $\alpha$ ). These cytokines induce nitric oxide synthesis and activate Th1 and CD8 ${ }^{+}$cytotoxic T-cells. Th1 cells enhance the secretion of IFN- $\gamma$ and TNF- $\alpha$, which are the influencing factors of the inflammatory response, Additionally, Th17, NKT, and NK cells can progress this disease. Th17 cells give IL-17, IL-17F, and IL-22 as pro-inflammatory cytokines. IL-17, IFN- $\gamma$, TNF- $\alpha$, induce the proliferation and activation of keratinocytes, resulting in more secretion of cytokines (IL-1, IL-6, TNF- $\alpha$ ), chemokines (CXCL8, CXCL11, CXCL20), and S100 proteins (S100A7-9) for infiltration of neutrophils and other phagocytic cells. Alternatively, diminution of Treg cell activity also the inductive factor in psoriasis. Thus, the multifactorial events are associated with psoriasis [103, 105-107]. Vitamin D deficiency impacts the development of psoriasis $[108,109]$ because it acts as an anti-inflammatory and anti-angiogenic agent [110].

Application of vitamin $\mathrm{D}_{3}$ or its analogs like calcipotriol, tacalcitol, and maxacalcitol can be used as the treatment agents of psoriasis [34, 111]. Phototherapy by using narrow-band UVB light also resolves the problem of psoriasis [112]. Active vitamin D suppresses the activity of pDCs, proliferation, and activation of T-cells, and release of IFN- $\gamma$ [113]. The effectiveness of CD8 ${ }^{+}$, Th1, and Th17 cells is suppressed by 1,25 $(\mathrm{OH})_{2} \mathrm{D}_{3}$ or its analog $[114,115]$. Moreover, vitamin D inhibits the expression of Il-12, IL-23, IL-1 $\alpha$, IL-1 $\beta$, TNF- $\alpha$, psoriasin (S100A7), and koebnerisin (S100A15) [116, 117]. Topical application of calcipotriol significantly reduces defensin- $\beta$ levels, as well as IL-17, IL-17F, and IL-8 to control the inflammation in psoriasis [118]. Another vitamin $\mathrm{D}$ analog $1 \alpha, 25$-dihydroxy vitamin $\mathrm{D}_{3}-3$-bromoacetate induces the expression of IL-22 that helps in the reconstruction of the epidermal layer by repressing the activity of protein kinase B (AKT1), mechanistic target of rapamycin (mTOR) pathway and release of IL-8, regulated upon activation normal T-cell expressed and secreted (RANTES), and psoriasin [119]. Vitamin D upregulates the expression of late cornified envelope (LCE) gene products LCE proteins to prevent psoriasis [120]. Vitamin D restores the normal texture of integrins, intercellular adhesion molecule-1 (ICAM-1), CD26, and HLA-DR that have appeared in an alternative form in psoriatic skin [121]. VDR polymorphisms (A-1012G, FokI, BsmI, ApaI, and TaqI) are associated with many diseases. A-1012G and Apal polymorphisms increase the risk of psoriasis [122].

\section{$\mathrm{AD}$}

AD is a chronic skin disease. Genetic and environmental factors in association with disruption of the epithelial barrier, immunological abnormalities, and IgE-mediated chronic inflammation influence AD. Impaired structural proteins (filaggrin, involucrin, loricrin, keratin K5, and K16, etc), alteration in subcutaneous $\mathrm{pH}$, low levels of skin ceramides are the cause of epithelial barrier disruption [123], leading to increased susceptibility of bacterial, fungal, and viral infection. The Th0 can differentiate into Th1 or Th2 cells [124]. The Th2 cytokines (IL-4, IL-5, and IL-13) are elevated during the acute phase, while Th1 cytokines [IFN- $\gamma$, granulocyte-macrophage colony-stimulating factor (GM-CSF), and IL-12] promote the chronic phase of inflammation. Tokura [125] reported that AD patients showed high levels of serum IgE. Thymic stromal 
lymphopoietin increases the maturation of naïve Th cells towards Th2 cells that start the release of IL-4, IL5, IL-13, and TNF- $\alpha$ for atopic lesions [126]. The DCs from myeloid origin promote Th1 polarization for the chronic reaction [127]. Moreover, the improper activity of NK cells, and neutrophils, defective TLR2 response, and reduced secretion of AMPs are also associated with AD [128, 129].

The low level of vitamin $\mathrm{D}$ increases the severity of AD. The prevalence of $\mathrm{AD}$ is high in the population living in higher geographic latitudes, with lower sun exposure [130]. Meta-analysis had shown that children and adults with AD had low levels of serum vitamin D [131]. VDR (BsmI, ApaI, and TaqI) and CYP24A1 polymorphisms increase the risk of AD [78, 132]. Supplementation of vitamin D restores the normal function of Th1 and Th2 cells [133]. Vitamin D can decrease the IFN- $\gamma$ and IL-17 in vitamin D-deficient individuals [134]. UVA/UVB phototherapy is also beneficial for AD treatment [112]. Vitamin D decreases the IgE producing B-cells in AD patients [135]. Albenali et al. [136] reported that supplementation of Vitamin D increased LL-37 level in AD patients.

\section{Vitiligo}

Vitiligo is an autoimmune disorder with a defective pigmentation process due to the destruction of functional melanocytes in the epidermis. The common characteristic of this disease is depigmented patches or macules of different shapes and sizes [137]. There is a genetic association with this disease. Vitiligo patients have genetic variants for the components of both the innate (NLRP1, IFIH1, CASP7, C1QTNF6, TRIF) and adaptive immunity (FOXP3, BACH2, CD80, CCR6, PTPN22, IL2R, alpha GZMB, HLA class I and II) [138]. In vitiligo patients, melanocytes are mostly affected. Autoantibody has been produced against melanin-concentrating hormone receptor 1 (MCHR1), tyrosinase, and cell surface antigen of melanocytes. The melanocyte-specific IgG and IgM are the predominant $[139,140]$. In this disease, T-cells exhibit more number of IL-2 receptors and a higher ratio of CD8:CD4. Cytotoxic CD8 T-cells undesirably attack melanocytes for destruction. Keratinocytes exhibit HLA-DR for local T-cell reactivity [141]. Th1 cells produce more IFN- $\gamma$ and TNF- $\alpha$ in the condition of vitiligo [142]. A significantly high level of IL-17 had observed in vitiliginous subjects [143].

Vitamin D deficiency is a contributing factor in the development of vitiligo. Several studies had indicated that a decreased level of vitamin D is significantly associated with vitiligo [144-146]. Vitamin D protects melanocyte proliferation, and integrity prevents T-cell-mediated damage and maintains the secretion of endothelin-3 (ET-3). Moreover, vitamin D restores the melanocyte viability and maturation by modulating the stem cell factor (SCF)/tyrosine kinase (c-Kit) pathway [147]. Active vitamin D reduces the expression of IL-6, IL-8, TNF- $\alpha$, and INF- $\gamma$, inhibits DC-mediated antigen presentation and immune activation [96]. Finamor et al. [111] reported that treatment with vitamin $\mathrm{D}_{3}$ (35,000 IU once daily) improved repigmentation in vitiligo patients. Birlea et al. [148] observed that vitamin $\mathrm{D}_{3}$ analogs in combination with plus UVA (PUVA), narrowband UVB (NBUVB) are effective for the treatment of vitiligo.

\section{Skin cancer}

Several etiological factors, including environmental toxicants, UV radiation, metabolic disorders, and chronic inflammatory response can progress cancer. Skin faces non-melanoma skin cancer (NMSC), including basal cell and squamous cell carcinoma, as well as melanoma $[149,150]$. Vitamin D decreases the risk of cancer. It protects the keratinocytes from UV radiation-mediated damage [151]. The deficiency of vitamin D increases the risk of melanoma [152]. On the other hand, the expression of VDR in melanocytes continuously declines as the cancers progressed. This effect increases the presence of tumor-infiltrating lymphocytes and the progression of ulceration [153]. Constitutive hedgehog signaling promotes basal cell carcinoma. Vitamin D reduces the expression of glioma-associated oncogene homolog 1 (Gli1) mRNA by inhibiting the hedgehog signaling pathway. Additionally, this inhibition also protects nucleotide excision repair enzymes to suppress the basal cell carcinomas $[150,154]$. Uncontrolled cell growth, angiogenesis, and metastasis are the fundamental events of cancerous growth. Vitamin D potentially inhibits the cell cycle, cell survival, angiogenesis, and metastasis to block tumor progression $[110,155]$. NF- $\kappa B$ signaling plays a vital role in the inflammatory response. Vitamin $\mathrm{D}_{3}$ inhibits NF- $\kappa \mathrm{B}$ translocation to the nucleus and its activity $[156,157]$. Melanoma cells express a specific transcription factor runt-related transcription factor 2 (RUNX2), which 
regulates the activity of focal adhesion kinase (FAK) that maintains the growth and mobility of cancer cells. Vitamin D analog cholecalciferol diminishes the transcriptional activity of RUNX2, followed by inhibition of progression of cancer [158]. Matrix metalloproteinases (MMPs) are essential for metastasis. Calcipotriol reduces the expression of MMPs by regulating the p38 and extracellular signal-regulated kinase (ERK) pathways [159]. FGF-2 is an angiogenic agent. The heparin-binding protein 17/FGF binding protein-1 (HBp17/FGFBP-1) is essential for the activity of FGF-2. Active vitamin $\mathrm{D}_{2}$ decreases the levels of HBp17/ FGFBP-1 and the activation of FGF-2 [160].

\section{Pemphigus vulgaris and bullous pemphigoid}

Pemphigus vulgaris and bullous pemphigoid are autoimmune bullous disorders that are mediated by keratinocyte-specific antibodies. Impaired activation of B-cells increases the production of pathogenic antibodies [24]. Low levels of serum vitamin D increase the risk of pemphigus vulgaris and bullous pemphigoid [161, 162]. Vitamin D is protective against this type of autoimmune disorder. This vitamin modulates Th2 cell differentiation, maturation of Treg cells and, apoptosis B-cells [24].

\section{Acne and rosacea}

Acne vulgaris is an inflammatory skin disease. Propionibacterium acnes involves in pathogenesis. This bacterium induces the maturation and activation of Th17, followed by the initiation of inflammatory response. $1,25(\mathrm{OH})_{2} \mathrm{D}$ inhibits Th17 differentiation [163]. Rosacea is a chronic skin disease mediated by high serum levels of vitamin D [164]. Thus, excess vitamin D is detrimental to the skin.

\section{Others}

There is a possibility for cutaneous fibrosis during vitamin D deficiency. Vitamin D can be the treatment choice against keloids as this vitamin inhibits skin fibroblasts and keloid fibroblasts [165]. Topical supplementation of vitamin D analogs can be used for the therapeutic purpose in morphoea and lichen sclerosus et atrophicus. Vitamin D analogs have the ability to regulate fibroblast proliferation, collagen synthesis, and endothelial cell function, as well as IL-2 secretion from T lymphocytes [166, 167]. UV light promotes skin damage, typically called photodamage, which is characterized by DNA damage, inflammatory responses, cutaneous cell apoptosis, skin aging, and skin carcinoma. The experimental study had revealed that vitamin $\mathrm{D}_{3}$ exhibits photoprotective effects $[168,169]$. Active vitamin D-VDR complex modulates $\beta$-catenin-mediated hair follicle differentiation and decreases hair loss $[24,170]$. Vitamin $D$ also regulates hedgehog signaling for recycling the hair follicle [171].

\section{Conclusion}

Vitamin D shows hormone-like activities through its intracellular nuclear receptor. Fish oil, egg, milk are the common dietary sources of this vitamin. Human skin synthesizes this vitamin from 7-dehydrocholesterol on exposure to sunlight. The active form of vitamin D is directly associated with skin functions. The cutaneous compartment is the greatest harbor of immune cells. Various environmental challenges activate the immune response in the skin. Vitamin D modulates the activity of immune cells. It maintains the cutaneous barrier, functions of keratinocytes, and controls the immune response starting from DC maturation, followed by T-cell activation, cytokine production, etc. This vitamin effectively suppresses the inflammatory response through the polarization of M2 macrophages, Th2 cells, and Treg cells. The deficiency of vitamin D causes calcium imbalance and many other disorders associated with impaired immune functions. Finally, it can be concluded that vitamin $\mathrm{D}$ is a potent immune regulator in the skin and exerts protection against several immune-related diseases including autoimmunity. Moreover, vitamin D can potentially be used as a therapeutic agent or may be applied as an adjuvant in the treatment purpose of skin diseases.

\section{Abbreviations}

AD: atopic dermatitis

AMPs: antimicrobial peptides 
APCs: antigen-presenting cells

CCL: CC chemokine ligand

CCR: CC-chemokine receptor

CXCL: C-X-C motif ligand

CYP: cytochrome P450

DBP: D-binding protein

DCs: dendritic cells

FGF: fibroblast growth factor

GlcCer: glucosylceramide

hCAP18: human cationic antimicrobial protein

HLA: human leukocyte antigen

IFN- $\alpha$ : interferon-alpha

IFN- $\gamma$ : interferon-gamma

Ig: immunoglobulin

IL: interleukin

KLK: kallikrein-related peptidase

LCs: Langerhans cells

LPS: lipopolysaccharides

NF-кB: nuclear factor kappa B

NK: natural killer

NLRs: nucleotide-binding oligomerization domain like receptors

PAMPs: pathogen-associated molecular patterns

pDCs: plasmacytoid dendritic cells

RANK: receptor activators of nuclear factor kappa B

RXR: retinoid X receptor

SRC: steroid receptor co-activator

TGF- $\beta$ : transforming growth factor- $\beta$

Th: T-helper

TLRs: Toll-like receptors

TNF- $\alpha$ : tumor necrosis factor-alpha

Treg: regulatory $\mathrm{T}$

UV: ultraviolet

VDRE: vitamin D response element

VDRs: vitamin D receptors

\section{Declarations}

\section{Acknowledgments}

The author is grateful to Midnapore College, Midnapore, West Bengal, India, for providing all kinds of facilities to prepare this manuscript.

\section{Author contributions}

The author contributed solely to the work. 


\section{Conflicts of interest}

The author has no conflict of interest.

\section{Ethical approval}

Not applicable.

\section{Consent to participate}

Not applicable.

\section{Consent to publication}

Not applicable.

Availability of data and materials

Not applicable.

\section{Funding}

Not applicable.

\section{Copyright}

(c) The Author(s) 2021.

\section{References}

1. Ibrahim KS, El-Sayed EM. Potential role of nutrients on immunity. Int Food Res J. 2016;23:464-74.

2. Aslam MF, Majeed S, Aslam S, Irfan JA. Vitamins: key role players in boosting up immune response-a mini review. Vitam Miner. 2017;6:153.

3. Mora JR, Iwata M, von Andrian UH. Vitamin effects on the immune system: vitamins A and D take centre stage. Nat Rev Immunol. 2008;8:685-98.

4. Aranow C. Vitamin D and the immune system. J Investig Med. 2011;59:881-6.

5. Maqbool MA, Aslam M, Akbar W, Iqbal Z. Biological importance of vitamins for human health: a review. J Agric Basic Sci. 2017;2:50-8.

6. Quaresma JAS. Organization of the skin immune system and compartmentalized immune responses in infectious diseases. Clin Microbiol Rev. 2019;32:e00034-18.

7. Abdayem R, Haftek M. The epidermal barrier. Ann Dermatol Venereol. 2018;145:293-301.

8. Ono S, Kabashima K. The role of dendritic cells and macrophages in the skin immunity. Nihon Rinsho Meneki Gakkai Kaishi. 2016;39:448-54.

9. Tay SS, Roediger B, Tong PL, Tikoo S, Weninger W. The skin-resident immune network. Curr Dermatol Rep. 2013;3:13-22.

10. Nestle FO, Di Meglio P, Qin JZ, Nickoloff BJ. Skin immune sentinels in health and disease. Nat Rev Immunol. 2009;9:679-91.

11. Elias PM, Wakefield JS. Mechanisms of abnormal lamellar body secretion and the dysfunctional skin barrier in patients with atopic dermatitis. J Allergy Clin Immunol. 2014;134:781-91.

12. Bikle DD. Vitamin D metabolism, mechanism of action, and clinical applications. Chem Biol. 2014;21:319-29.

13. Sigmundsdottir H, Pan J, Debes GF, Alt C, Habtezion A, Soler D, et al. DCs metabolize sunlightinduced vitamin $\mathrm{D}_{3}$ to 'program' T cell attraction to the epidermal chemokine CCL27. Nat Immunol. 2007;8:285-93 
14. Cantorna MT, Snyder L, Arora J. Vitamin A and vitamin D regulate the microbial complexity, barrier function, and the mucosal immune responses to ensure intestinal homeostasis. Crit Rev Biochem Mol Biol. 2019;54:184-92.

15. Cyprian F, Lefkou E, Varoudi K, Girardi G. Immunomodulatory effects of vitamin D in pregnancy and beyond. Front Immunol. 2019;10:2739.

16. Yamamoto EA. Jørgensen TN. Relationships between vitamin D, gut microbiome, and systemic autoimmunity. Front Immunol. 2020;10:3141.

17. Clemens TL, Adams JS, Henderson SL, Holick MF. Increased skin pigment reduces the capacity of skin to synthesize vitamin $\mathrm{D}_{3}$. Lancet. 1982;1:74-6.

18. Holick MF. Vitamin D deficiency. N Engl J Med. 2007;357:266-81.

19. Tsiaras WG, Weinstock MA. Factors influencing vitamin D status. Acta Derm Venereol. 2011;91:115-24.

20. Ardawi MS, Qari MH, Rouzi AA, Maimani AA, Raddadi RM. Vitamin D status in relation to obesity, bone mineral density, bone turnover markers and vitamin D receptor genotypes in healthy Saudi pre- and postmenopausal women. Osteoporos Int. 2011;22:463-75.

21. Zittermann A, Frisch S, Berthold HK, Götting C, Kuhn J, Kleesiek K, et al. Vitamin D supplementation enhances the beneficial effects of weight loss on cardiovascular risk markers. Am J Clin Nutr. 2009;89:1321-7.

22. Riccioni G, D’Orazio N, Menna V, De Lorenzo A. Fat soluble vitamins and immune system: an overview. Eur J Inflam. 2003;1:59-64.

23. Bikle D. Nonclassic actions of vitamin D. J Clin Endocrinol Metab. 2009;94:26-34.

24. Mostafa WZ, Hegazy RA. Vitamin D and the skin: focus on a complex relationship: a review. J Adv Res. 2015;6:793-804.

25. Christakos S, Dhawan P, Verstuyf A, Verlinden L, Carmeliet G. Vitamin D: metabolism, molecular mechanism of action, and pleiotropic effects. Physiol Rev. 2016;96:365-408.

26. Sadarangani SP, Whitaker JA, Poland GA. Let there be light: the role of vitamin D in the immune response to vaccines. Expert Rev Vaccines. 2015;14:1427-40.

27. van Etten E, Stoffels K, Gysemans C, Mathieu C, Overbergh L. Regulation of vitamin D homeostasis: implications for the immune system. Nutr Rev. 2008;66 Suppl 2:S125-34.

28. Shahriari M, Kerr PE, Slade K, Grant-Kels JE. Vitamin D and the skin. Clin Dermatol. 2010;28:663-8.

29. Mazzaferro S, Pasquali M. Vitamin D: a dynamic molecule. How relevant might the dynamism for a vitamin be? Nephrol Dial Transplant. 2016;31:23-30.

30. Chirumbolo S, Bjørklund G, Sboarina A, Vella A. The role of vitamin D in the immune system as a prosurvival molecule. Clin Ther. 2017;39:894-916.

31. Sasaki H, Harada H, Handa Y, Morino H, Suzawa M, Shimpo E, et al. Transcriptional activity of a fluorinated vitamin D analog on VDR-RXR-mediated gene expression. Biochemistry. 1995;34:370-7.

32. Shah S, Islam MN, Dakshanamurthy S, Rizvi I, Rao M, Herrell R, et al. The molecular basis of vitamin D receptor and $\beta$-catenin crossregulation. Mol Cell. 2006;21:799-809.

33. Yousef H, Miao JH, Alhajj M, Badri T. Histology, skin appendages [Internet]. Treasure Island (FL): StatPearls Publishing; c2021 [Updated 2021 Apr 29; cited 2021 Mar 16]. Available from: https://www. ncbi.nlm.nih.gov/books/NBK482237/

34. Umar M, Sastry KS, Al Ali F, Al-Khulaifi M, Wang E, Chouchane AI. Vitamin D and the pathophysiology of inflammatory skin diseases. Skin Pharmacol Physiol. 2018;31:74-86.

35. Oda Y, Uchida Y, Moradian S, Crumrine D, Elias PM, Bikle DD. Vitamin D receptor and co-activators SRC 2 and 3 regulate epidermis-specific sphingolipid production and permeability barrier formation. J Invest Dermatol. 2009;129:1367-78. 
36. Gniadecki R. Stimulation versus inhibition of keratinocyte growth by 1,25-dihydroxyvitamin $\mathrm{D}_{3}$ : dependence on cell culture conditions. J Invest Dermatol. 1996;106:510-6.

37. Bikle DD. Vitamin D and the skin: physiology and pathophysiology. Rev Endocr Metab Disord. 2012;13:3-19.

38. Bikle DD, Ng D, Tu CL, Oda Y, Xie Z. Calcium- and vitamin D-regulated keratinocyte differentiation. Mol Cell Endocrinol. 2001;177:161-71.

39. Xie Z, Komuves L, Yu QC, Elalieh H, Ng DC, Leary C, et al. Lack of the vitamin D receptor is associated with reduced epidermal differentiation and hair follicle growth. J Invest Dermatol. 2002;118:11-6.

40. Debeer S, Le Luduec JB, Kaiserlian D, Laurent P, Nicolas JF, Dubois B, et al. Comparative histology and immunohistochemistry of porcine versus human skin. Eur J Dermatol. 2013;23:456-66.

41. Matejuk A. Skin immunity. Arch Immunol Ther Exp (Warsz). 2018;66:45-54.

42. Merad M, Ginhoux F,Collin M. Origin, homeostasis and function of Langerhans cells and other langerinexpressing dendritic cells. Nat Rev Immunol. 2008;8:935-47

43. Lai Y, Gallo RL. Toll-like receptors in skin infections and inflammatory diseases. Infect Disord Drug Targets. 2008;8:144-55.

44. Newton K, Dixit VM. Signaling in innate immunity and inflammation. Cold Spring Harb Perspect Biol. 2012;4:a006049.

45. Coll RC, Robertson AA, Chae JJ, Higgins SC, Muñoz-Planillo R, Inserra MC, et al. A small-molecule inhibitor of the NLRP3 inflammasome for the treatment of inflammatory diseases. Nat Med. 2015:21:248-55.

46. Keller M, Rüegg A, Werner S, Beer HD. Active caspase-1 is a regulator of unconventional protein secretion. Cell. 2008;132:818-31.

47. Albanesi C, Scarponi C, Giustizieri ML, Girolomoni G. Keratinocytes in inflammatory skin diseases. Curr Drug Targets Inflamm Allergy. 2005;4:329-34.

48. Black AP, Ardern-Jones MR, Kasprowicz V, Bowness P, Jones L, Bailey AS, et al. Human keratinocyte induction of rapid effector function in antigen-specific memory $\mathrm{CD} 4^{+}$and $\mathrm{CD} 8^{+} \mathrm{T}$ cells. Eur J Immunol. 2007;37:1485-93.

49. Tremante E, Ginebri A, Lo Monaco E, Benassi B, Frascione P, Grammatico P, et al. A melanoma immune response signature including human leukocyte antigen-E. Pigment Cell Melanoma Res. 2014;27:103-12.

50. Kaisho T, Akira S. Toll-like receptor function and signaling. J Allergy Clin Immunol Pract. 2006;117:979-87.

51. Shklovskaya E, O'Sullivan BJ, Ng LG, Roediger B, Thomas R, Weninger W, et al. Langerhans cells are precommitted to immune tolerance induction. Proc Natl Acad Sci USA. 2011;108:18049-54.

52. Yoshiki R, Kabashima K, Sugita K, Atarashi K, Shimauchi T, Tokura Y. IL-10-producing Langerhans cells and regulatory $\mathrm{T}$ cells are responsible for depressed contact hypersensitivity in grafted skin. J Invest Dermatol. 2009;129:705-13.

53. Gomez de Agüero M, Vocanson M, Hacini-Rachinel F, Taillardet M, Sparwasser T, Kissenpfennig A, et al. Langerhans cells protect from allergic contact dermatitis in mice by tolerizing $\mathrm{CD} 8^{+} \mathrm{T}$ cells and activating Foxp3 ${ }^{+}$regulatory T cells. J Clin Invest. 2012;122:1700-11.

54. Klechevsky E. Functional diversity of human dendritic cells. Adv Exp Med Biol. 2015;850:43-54.

55. Clark RA, Chong B, Mirchandani N, Brinster NK, Yamanaka K, Dowgiert RK, et al. The vast majority of $\mathrm{CLA}^{+} \mathrm{T}$ cells are resident in normal skin. J Immunol. 2006;176:4431-9.

56. Mueller SN, Gebhardt T, Carbone FR, Heath WR. Memory T cell subsets, migration patterns, and tissue residence. Annu Rev Immunol. 2013;31:137-61.

57. Nomura T, Kabashima K, Miyachi Y. The panoply of $\alpha \beta$ T cells in the skin. J Dermatol Sci. 2014;76:3-9.

58. Bos JD, Kapsenberg ML. The skin immune system: progress incutaneous biology. Immunol Today. 1993;14:75-8. 
59. Foster CA, Yokozeki H, Rappersberger K, Koning F, Volc-Platzer B, Rieger A, et al. Human epidermal $\mathrm{T}$ cells predominantly belong to the lineage expressing alpha/beta $\mathrm{T}$ cell receptor. J Exp Med. 1990;171:997-1013.

60. Schenkel JM, Masopust D. Tissue-resident memory T cells. Immunity. 2014;41:886-97.

61. Abdallah F, Mijouin L, Pichon C. Skin immune landscape: inside and outside the organism. Mediators of Inflammation. 2017;2017:5095293.

62. Kabashima K, Nakashima C, Nonomura Y, Otsuka A, Cardamone C, Parente R, et al. Biomarkers for evaluation of mast cell and basophil activation. Immunol Rev. 2018;282:114-20.

63. Rusek P, Wala M, Druszczyńska M, Fol M. Infectious agents as stimuli of trained innate immunity. Int J Mol Sci. 2018;19:456.

64. Geherin SA, Fintushel SR, Lee MH, Wilson RP, Patel RT, Alt C, et al. The skin, a novel niche for recirculating B cells. J Immunol. 2012;188:6027-35.

65. Holtfreter S, Kolata J, Bröker BM. Towards the immune proteome of Staphylococcus aureus-the anti-S. aureus antibody response. Int J Med Microbiol. 2010;300:176-92.

66. Berthelot JM, Jamin C, Amrouche K, Le Goff B, Maugars Y, Youinou P. Regulatory B cells play a key role in immune system balance. Joint Bone Spine. 2013;80:18-22.

67. Toniato E, Spinas E, Saggini A, Kritas SK, Caraffa A, Antinolfi P. et al. Immunomodulatory effects of vitamin D on skin inflammation. J Biol Regul Homeost Agents. 2015;29:563-7.

68. Schauber J, Gallo RL. Antimicrobial peptides and the skin immune defense system. J Allergy Clin Immunol Pract. 2008;122:261-6.

69. Gallo RL, Hooper LV. Epithelial antimicrobial defence of the skin and intestine. Nat Rev Immunol. 2012;12:503-16.

70. Liang SC, Tan XY, Luxenberg DP, Karim R, Dunussi-Joannopoulos K, Collins M, et al. Interleukin (IL)22 and IL-17 are coexpressed by Th17 cells and cooperatively enhance expression of antimicrobial peptides. J Exp Med. 2006;203:2271-9.

71. Vanchinathan V, Lim HW. A dermatologist's perspective on vitamin D. Mayo Clin Proc. 2012;87:372-80.

72. Goldsmith JR. Vitamin D as an immunomodulator: risks with deficiencies and benefits of supplementation. Healthcare (Basel). 2015;3:219-32.

73. Yamamoto E, Jørgensen TN. Immunological effects of vitamin D and their relations to autoimmunity. J Autoimmun. 2019;100:7-16.

74. Brosbøl-Ravnborg A, Bundgaard B, Höllsberg P. Synergy between vitamin $\mathrm{D}_{3}$ and toll-like receptor agonists regulates human dendritic cell response during maturation. Clin Dev Immunol. 2013;2013:807971.

75. Rizvi I, Garg RK, Jain A, Malhotra HS, Singh AK, Prakash S, et al. Vitamin D status, vitamin D receptor and toll like receptor-2 polymorphisms in tuberculous meningitis: a case-control study. Infection. 2016;44:633-40.

76. Kizildag S, Dedemoglu F, Anik A, Catli G, Kizildag S, Abaci A, et al. Association between vitamin D receptor polymorphism and familial Mediterranean fever disease in Turkish children. Biochem Genet. 2016;54:169-76.

77. Kılıç S, Sılan F, Hız MM, Işık S, Ögretmen Z, Özdemir Ö. Vitamin D receptor gene BSMI, FOKI, APAI, and TAQI polymor-phisms and the risk of atopic dermatitis. J Investig Allergol Clin Immunol 2016;26:106-10.

78. van der Eerden BC, van der Heyden JC, van Hamburg JP, Schreuders-Koedam M, Asmawidjaja PS, de Muinck Keizer-Schrama SM, et al. A human vitamin D receptor mutation causes rickets and impaired Th1/Th17 responses. Bone. 2014;69:6-11. 
79. Weber G, Heilborn JD, Chamorro Jimenez CI, Hammarsjo A, Törmä H, Stahle M. Vitamin D induces the antimicrobial protein hCAP18 in human skin. J Invest Dermatol. 2005;124:1080-2.

80. Schauber J, Dorschner RA, Coda AB, Büchau AS, Liu PT, Kiken D, et al. Injury enhances TLR2 function and antimicrobial peptide expression through a vitamin D-dependent mechanism. J Clin Invest. 2007;117:803-11.

81. Liu PT, Schenk M, Walker VP, Dempsey PW, Kanchanapoomi M, Wheelwright M, et al. Convergence of IL-1beta and VDR activation pathways in human TLR2/1-induced antimicrobial responses. PLoS One. 2009;4:e5810.

82. Lee WJ, Cha HW, Sohn MY, Lee SJ, Kim DW. Vitamin D increases expression of cathelicidin in cultured sebocytes. Arch Dermatol Res. 2012;304:627-32.

83. Dai X, Sayama K, Tohyama M, Shirakata Y, Hanakawa Y, Tokumaru S, et al. PPARgamma mediates innate immunity by regulating the 1alpha,25-dihydroxyvitamin $\mathrm{D}_{3}$ induced hBD-3 and cathelicidin in human keratinocytes. J Dermatol Sci. 2010;60:179-86.

84. Yamasaki K, Schauber J, Coda A, Lin H, Dorschner RA, Schechter NM, et al. Kallikrein-mediated proteolysis regulates the antimicrobial effects of cathelicidins in skin. FASEB J. 2006;20:2068-80.

85. Morizane S, Yamasaki K, Kabigting FD, Gallo RL. Kallikrein expression and cathelicidin processing are independently controlled in keratinocytes by calcium, vitamin $\mathrm{D}_{3}$, and retinoic acid. J Invest Dermatol. 2010;130:1297-306.

86. Antal AS, Dombrowski Y, Koglin S, Ruzicka T, Schauber J. Impact of vitamin $\mathrm{D}_{3}$ on cutaneous immunity and antimicrobial peptide expression. Dermatoendocrinol. 2011;3:18-22.

87. Chen L, Eapen MS, Zosky GR. Vitamin D both facilitates and attenuates the cellular response to lipopolysaccharide. Sci Rep. 2017;7:45172.

88. Liang S, Cai J, Li Y, Yang R. 1,25-dihydroxy-vitamin $\mathrm{D}_{3}$ induces macrophage polarization to M2 by upregulating T-cell Ig-mucin-3 expression. Mol Med Rep. 2019;19:3707-13.

89. Almerighi C, Sinistro A, Cavazza A, Ciaprini C, Rocchi G, Bergamini A. 1alpha,25-dihydroxyvitamin $\mathrm{D}_{3}$ inhibits CD40L-induced pro-inflammatory and immunomodulatory activity in human monocytes. Cytokine. 2009;45:190-7.

90. Klug-Micu GM, Stenger S, Sommer A, Liu PT, Krutzik SR, Modlin RL, et al. CD40 ligand and interferon-g induce an antimicrobial response against Mycobacterium tuberculosis in human monocytes. Immunol. 2013;139:121-8.

91. Khoo AL, Koenen HJ, Michels M, Ooms S, Bosch M, Netea MG, et al. High-dose vitamin $\mathrm{D}_{3}$ supplementation is a requisite for modulation of skin-homing markers on regulatory T cells in HIV-infected patients. AIDS Res Hum Retroviruses. 2013;29:299-306.

92. Jeffery LE, Burke F, Mura M, Zheng Y, Qureshi OS, Hewison M, et al. 1,25-dihydroxyvitamin $\mathrm{D}_{3}$ and IL-2 combine to inhibit $\mathrm{T}$ cell production of inflammatory cytokines and promote development of regulatory T cells expressing CTLA-4 and FoxP3. J Immunol. 2009;183:5458-67.

93. Looman KIM, Jansen MAE, Voortman T, van den Heuvel D, Jaddoe VWV, Franco OH, et al. The role of vitamin D on circulating memory T cells in children: The generation R study. Pediatr. Allergy Immunol. 2017;28:579-87.

94. Dam TN, Møller B, Hindkjaer J, Kragballe K. The vitamin $\mathrm{D}_{3}$ analog calcipotriol suppresses the number and antigen-presenting function of Langerhans cells in normal human skin. J Investig Dermatol Symp Proc. 1996;1:72-7.

95. Chen S, Sims GP, Chen XX, Gu YY, Chen S, Lipsky PE. Modulatory effects of 1,25-dihydroxyvitamin $\mathrm{D}_{3}$ on human B cell differentiation. J Immunol. 2007;179:1634-47.

96. Penna G, Adorini L. 1 alpha,25-dihydroxyvitamin $\mathrm{D}_{3}$ inhibits differentiation, maturation, activation, and survival of dendritic cells leading to impaired alloreactive $\mathrm{T}$ cell activation. J Immunol. 2000;164:2405-11. 
97. Baeke F, Korf H, Overbergh L, Verstuyf A, Thorrez L, Van Lommel L, et al. The vitamin D analog, TX527, promotes a human $\mathrm{CD} 4$ ? $\mathrm{CD} 25^{\text {high }} \mathrm{CD} 127^{\text {low }}$ regulatory $\mathrm{T}$ cell profile and induces a migratory signature specific for homing to sites of inflammation. J Immunol. 2011;186:132-42.

98. Ghoreishi M, Bach P, Obst J, Komba M, Fleet JC, Dutz JP. Expansion of antigen-specific regulatory T cells with the topical vitamin D analog calcipotriol. J Immunol. 2009;182:6071-8.

99. Adorini L, Penna G. Dendritic cell tolerogenicity: a key mechanism in immunomodulation by vitamin D receptor agonists. Hum Immunol. 2009:70,345-52.

100. Adorini L, Penna G, Giarratana N, Uskokovic M. Tolerogenic dendritic cells induced by vitamin D receptor ligands enhance regulatory $\mathrm{T}$ cells inhibiting allograft rejection and autoimmune diseases. J Cell Biochem. 2003;88:227-33.

101. Gorman S, Geldenhuys S, Judge M, Weeden CE, Waithman J, Hart PH. Dietary vitamin D increases percentages and function of regulatory $\mathrm{T}$ cells in the skin-draining lymph nodes and suppresses dermal inflammation. J Immunol Res. 2016;2016:1426503.

102. Wadhwa B, Relhan V, Goel K, Kochhar AM, Garg VK. Vitamin D and skin diseases: a review. Indian J Dermatol Venereol Leprol. 2015;81:344-55.

103. Cai Y, Fleming C, Yan J. New insights of T cells in the pathogenesis of psoriasis. Cell Mol Immunol. 2012;9:302-9.

104. Lande R, Gregorio J, Facchinetti V, Chatterjee B, Wang YH, Homey B, et al. Plasmacytoid dendritic cells sense self-DNA coupled with antimicrobial peptide. Nature. 2007;449:564-9.

105. Sugiyama H, Gyulai R, Toichi E, Garaczi E, Shimada S, Stevens SR, et al. Dysfunctional blood and target tissue $\mathrm{CD} 4^{+} \mathrm{CD} 25^{\text {high }}$ regulatory $\mathrm{T}$ cells in psoriasis: mechanism underlying unrestrained pathogenic effector T cell proliferation. J Immunol. 2005;174:164-73.

106. Nestle FO, Kaplan DH, Barker J. Psoriasis. N Engl J Med. 2009;361:496-509.

107. Mattozzi C, Salvi M, D’Epiro S, Giancristoforo S, Macaluso L, Luci C, et al. Importance of regulatory T cells in the pathogenesis of psoriasis: review of the literature. Dermatology. 2013;227:134-45.

108. Mattozzi C, Paolino G, Salvi M, Macaluso L, Luci C, Morrone S, et al. Peripheral blood regulatory T cell measurements correlate with serum vitamin D level in patients with psoriasis. Eur Rev Med Pharmacol Sci. 2016;20:1675-9.

109. Maleki M, Nahidi Y, Azizahari S, Meibodi NT, Hadianfar A. Serum 25-OH vitamin D level in psoriatic patients and comparison with control subjects. J Cutan Med Surg. 2016;20:207-10.

110. Picotto G, Liaudat AC, Bohl L, Tolosa de Talamoni N. Molecular aspects of vitamin D anticancer activity. Cancer Invest. 2012;30:604-14.

111. Finamor DC, Sinigaglia-Coimbra R, Neves LC, Gutierrez M, Silva JJ, Torres LD, et al. A pilot study assessing the effect of prolonged administration of high daily doses of vitamin $\mathrm{D}$ on the clinical course of vitiligo and psoriasis. Dermatoendocrinol. 2013;5:222-34.

112. Le P, Tu J, Gebauer K, Brown S. Serum 25-hydroxyvitamin D increases with NB-UVB and UVA/UVB phototherapy in patients with psoriasis and atopic dermatitis in Western Australia. Australas J Dermatol. 2016;57:115-21.

113. Karthaus N, van Spriel AB, Looman MWG, Chen S, Spilgies LM, Lieben L, et al. Vitamin D controls murine and human plasmacytoid dendritic cell function. J Invest Dermatol. 2014;134:1255-64.

114. Lemire JM, Adams JS, Kermani-Arab V, Bakke AC, Sakai R, Jordan SC. 1,25-Dihydroxyvitamin $D_{3}$ suppresses human T helper/inducer lymphocyte activity in vitro. J Immunol. 1985;134:3032-5.

115. Dyring-Andersen B, Bonefeld CM, Bzorek M, Løvendorf MB, Lauritsen JP, Skov L, et al. The vitamin D analogue calcipotriol reduces the frequency of $\mathrm{CD} 8^{+} \mathrm{IL}-17^{+} \mathrm{T}$ cells in psoriasis lesions. Scand J Immunol. 2015;82:84-91 
116. Balato A, Schiattarella M, Lembo S, Mattii M, Prevete N, Balato N, et al. Interleukin-1 family members are enhanced in psoriasis and suppressed by vitamin D and retinoic acid. Arch Dermatol Res. 2013;305:255-62.

117. Hegyi Z, Zwicker S, Bureik D, Peric M, Koglin S, Batycka-Baran A, et al. Vitamin D analog calcipotriol suppresses the Th17 cytokine-induced proinflammatory S100 "alarmins" psoriasin (S100A7) and koebnerisin (S100A15) in psoriasis. J Invest Dermatol. 2012;132:1416-24.

118. Peric M, Koglin S, Dombrowski Y, Gross K, Bradac E, Büchau A, et al. Vitamin D analogs differentially control antimicrobial peptide/"Alarmin" expression in psoriasis. PLoS One. 2009;4:e6340.

119. Datta Mitra A, Raychaudhuri SP, Abria CJ, Mitra A, Wright R, Ray R, et al. 1alpha,25-Dihydroxyvitamin$\mathrm{D}_{3}$-3-bromoacetate regulates AKT/mTOR signaling cascades: a therapeutic agent for psoriasis. J Invest Dermatol. 2013;133:1556-64.

120. Hoss E, Austin HR, Batie SF, Jurutka PW, Haussler MR, Whitfield GK. Control of late cornified envelope genes relevant to psoriasis risk: upregulation by 1,25-dihydroxyvitamin $\mathrm{D}_{3}$ and plant-derived delphinidin. Arch Dermatol Res. 2013;305:867-78.

121. Savoia P, Novelli M, De Matteis A, Verrone A, Bernengo MG. Effects of topical calcipotriol on the expression of adhesion molecules in psoriasis. J Cutan Pathol. 1998;25:89-94.

122. Zhou X, Xu LD, Li YZ. The association of polymorphisms of the vitamin D receptor gene with psoriasis in the Han population of northeastern China. J Dermatol Sci. 2014;73:63-6.

123. Bieber T. Atopic dermatitis. Ann Dermatol. 2010;22:125-37.

124. Bieber T. Atopic dermatitis. N Engl J Med. 2008;358:1483-94.

125. Tokura Y. Extrinsic and intrinsic types of atopic dermatitis. J Dermatol Sci. 2010;58:1-7.

126. Soumelis V, Reche PA, Kanzler H, Yuan W, Edward G, Homey B, et al. Human epithelial cells trigger dendritic cell mediated allergic inflammation by producing TSLP. Nat Immunol. 2002;3:673-80.

127. Said A, Weindl G. Regulation of dendritic cell function in inflammation. J Immunol Res. 2015;2015:743169.

128. De Benedetto A, Agnihothri R, McGirt LY, Bankova LG, Beck LA. Atopic dermatitis: a disease caused by innate immune defects? J Invest Dermatol. 2009;129:14-30.

129. Hata TR, Gallo RL. Antimicrobial peptides, skin infections, and atopic dermatitis. Semin Cutan Med Surg. 2008;27:144-50.

130. Weiland SK, Hüsing A, Strachan DP, Rzehak P, Pearce N; ISAAC phase one study group. Climate and the prevalence of symptoms of asthma, allergic rhinitis, and atopic eczema in children. Occup Environ Med. 2004;61:609-15.

131. Kim MJ, Kim SN, Lee YW, Choe YB, Ahn KJ. Vitamin D status and efficacy of vitamin D supplementation in atopic dermatitis: a systematic review and meta-analysis. Nutrients. 2016;8:789.

132. Hallau J, Hamann L, Schumann RR, Worm M, Heine G. A promoter polymorphism of the vitamin D metabolism gene Cyp24a1 is associated with severe atopic dermatitis in adults. Acta Derm Venereol. 2016;96:169-72.

133. Di Filippo P, Scaparrotta A, Rapino D, Cingolani A, Attanasi M, Petrosino MI, et al. Vitamin D supplementation modulates the immune system and improves atopic dermatitis in children. Int Arch Allergy Immunol. 2015;166:91-6.

134. Drozdenko G, Heine G, Worm M. Oral vitamin D increases the frequencies of CD38 ${ }^{+}$human B cells and ameliorates IL-17-producing T cells. Exp Dermatol. 2014;23:107-12.

135. Yip KH, Kolesnikoff N, Yu C, Hauschild N, Taing H, Biggs L, et al. Mechanisms of vitamin $\mathrm{D}_{3}$ metabolite repression of IgE-dependent mast cell activation. J Allergy Clin Immunol. 2014;133:1356-64,1364. e1-14. 
136. Albenali LH, Danby S, Moustafa M, Brown K, Chittock J, Shackley F, et al. Vitamin D and antimicrobial peptide levels in patients with atopic dermatitis and atopic dermatitis complicated by eczema herpeticum: a pilot study. J Allergy Clin Immunol. 2016;138:1715-19.e4.

137. AlGhamdi KM, Kumar A. Depigmentation therapies for normal skin in vitiligo universalis. J Eur Acad Dermatol Venereol. 2011;25:749-57.

138. Rashighi M, Harris JE. Vitiligo pathogenesis and emerging treatments dermatol clin. 2017;35:257-65.

139. Harning R, Cui J, Bystryn JC. Relation between the incidence and level of pigment cell antibodies and disease activity in vitiligo. J Invest Dermatol. 1991;97:1078-80.

140. Arora AK, Kumaran MS. Pathogenesis of vitiligo: an update. Pigment Int. 2017;4:65-77.

141. Le Poole IC, van den Wijngaard RM, Westerhof W, Das PK. Presence of T cells and macrophages in inflammatory vitiligo skin parallels melanocyte disappearance. Am J Pathol. 1996;148:1219-28.

142. Taher ZA, Lauzon G, Maguiness S, Dytoc MT. Analysis of interleukin-10 levels in lesions of vitiligo following treatment with topical tacrolimus. Br J Dermatol. 2009;161:654-9.

143. Bassiouny DA, Shaker 0. Role of interleukin-17 in the pathogenesis of vitiligo. Clin Exp Dermatol. 2011;36:292-7.

144. Silverberg JI, Silverberg AI, Malka E, Silverberg NB. A pilot study assessing the role of 25 hydroxy vitamin D levels in patients with vitiligo vulgaris. J Am Acad Dermatol. 2010;62:937-41.

145. Li K, Shi Q, Yang L, Li X, Liu L, Wang L, et al. The association of vitamin D receptor gene polymorphisms and serum 25-hydroxyvitamin D levels with generalized vitiligo. Br J Dermatol. 2012;167:815-21.

146. Saleh HM, Abdel Fattah NS, Hamza HT. Evaluation of serum 25-hydroxyvitamin D levels in vitiligo patients with and without autoimmune diseases. Photodermatol Photoimmunol Photomed. 2013;29:34-40.

147. Alghamdi K, Kumar A, Moussa N. The role of vitamin D in melanogenesis with an emphasis on vitiligo. Indian J Dermatol Venereol Leprol. 2013;79:750-8.

148. Birlea SA, Costin GE, Norri DA. New insights on therapy with vitamin D analogs targeting the intracellular pathways that control repigmentation in human vitiligo. Med Res Rev. 2009;29:514-46.

149. Lehmann B, Querings K, Reichrath J. Vitamin D and skin: new aspects for dermatology. Exp Dermatol. 2004;13 Suppl 4:11-5.

150. Tang JY, Fu T, Lau C, Oh DH, Bikle DD, Asgari MM. Vitamin D in cutaneous carcinogenesis: part II. J Am Acad Dermatol. 2012;67: 817.e1-11;quiz 827-8.

151. Langberg M, Rotem C, Fenig E, Koren R, Ravid A. Vitamin D protects keratinocytes from deleterious effects of ionizing radiation. Br J Dermatol. 2009;160:151-61.

152. Nürnberg B, Gräber S, Gärtner B, Geisel J, Pföhler C, Schadendorf D, et al. Reduced serum 25hydroxyvitamin D levels in stage IV melanoma patients. Anticancer Res. 2009;29:3669-74.

153. Brozyna AA, Jóźwicki W, Slominski AT. Decreased VDR expression in cutaneous melanomas as marker of tumor progression: new data and analyses. Anticancer Res. 2014; 34:2735-43.

154. Tang JY, Xiao TZ, Oda Y, Chang KS, Shpall E, Wu A, et al. Vitamin $\mathrm{D}_{3}$ inhibits hedgehog signaling and proliferation in murine basal cell carcinomas. Cancer Prev Res (Phila). 2011;4:744-51.

155. Nemazannikova N, Antonas K, Dass CR. Role of vitamin D metabolism in cutaneous tumour formation and progression. J Pharm Pharmacol. 2013;65:2-10.

156. Janjetovic Z, Brozyna AA, Tuckey RC, Kim TK, Nguyen MN, Jozwicki W, et al. High basal NF-kappaB activity in nonpigmented melanoma cells is associated with an enhanced sensitivity to vitamin $\mathrm{D}_{3}$ derivatives. $\mathrm{Br}$ J Cancer. 2011;105:1874-84.

157. Yuan K, Madu CO, Lu Y. Immunological role of vitamin D in skin siseases and carcinoma. Oncomed. 2017;2:52-60.

158. Boregowda RK, Olabisi OO, Abushahba W, Jeong BS, Haenssen KK, Chen W, et al. RUNX2 is overexpressed in melanoma cells and mediates their migration and invasion. Cancer Lett. 2014;348:61-70. 
159. Meephansan J, Komine M, Tsuda H, Ohtsuki M. Suppressive effect of calcipotriol on the induction of matrix metalloproteinase (MMP)-9 and MMP-13 in a human squamous cell carcinoma cell line. Clin Exp Dermatol. 2012;37:889-96.

160. Rosli SN, Shintani T, Toratani S, Usui E, Okamoto T. 1alpha,25(OH)D inhibits FGF-2 release from oral squamous cell carcinoma cells through down-regulation of HBp17/FGFBP-1. In Vitro Cell Dev Biol Anim. 2014;50:802-6.

161. El-Komy MH, Samir N, Shaker OG. Estimation of vitamin D levels in patients with pemphigus vulgaris. J Eur Acad Dermatol Venereol. 2014:28:859-63.

162. Marzano AV, Trevisan V, Eller-Vainicher C, Cairoli E, Marchese L, Morelli V, et al. Evidence for vitamin D deficiency and increased prevalence of fractures in autoimmune bullous skin diseases. Br J Dermatol. 2012;167:688-91.

163. Agak GW, Qin M, Nobe J, Kim MH, Krutzik SR, Tristan GR, et al. Propionibacterium acnes induces an IL-17 response in acne vulgaris that is regulated by vitamin A and vitamin D. J Invest Dermatol. 2014;134:366-73.

164. Ekiz O, Balta I, Sen BB, Dikilitaş MC, Ozuğuz P, Rifaioğlu EN. Vitamin D status in patients with rosacea. Cutan Ocul Toxicol. 2014;33:60-2.

165. Zhang GY, Cheng T, Luan Q, Liao T, Nie CL, Zheng X, et al. Vitamin D: a novel therapeutic approach for keloid, an in vitro analysis. Br J Dermatol. 2011;164:729-37.

166. Boelsma E, Pavel S, Ponec M. Effects of calcitriol on fibroblasts derived from skin of scleroderma patients. Dermatol. 1995;191:226-33.

167. Bhalla AK, Amento EP, Serog B, Glimcher LH. 1,25-dihydroxyvitamin $\mathrm{D}_{3}$ inhibits antigen-induced T cell activation. J Immunol. 1984;133:1748-54.

168. Lee J, Youn JI. The photoprotective effect of 1,25-dihydroxyvitamin $\mathrm{D}_{3}$ on ultraviolet light B-induced damage in keratinocyte and its mechanism of action. J Dermatol Sci. 1998;18:11-8.

169. Dixon KM, Deo SS, Norman AW, Bishop JE, Halliday GM, Reeve VE, et al. In vivo relevance for photoprotection by the vitamin D rapid response pathway. J Steroid Biochem Mol Biol. 2007;103:451-6.

170. Demay MB. The hair cycle and vitamin D receptor. Arch Biochem Biophys. 2012;523:19-21.

171. Teichert A, Elalieh H, Bikle D. Disruption of the hedgehog signaling pathway contributes to the hair follicle cycling deficiency in Vdr knockout mice. J Cell Physiol. 2010;225:482-9. 